\begin{tabular}{|c|c|}
\hline 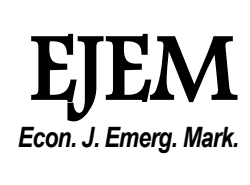 & $\begin{array}{c}\text { ECONOMIC JOURNAL OF } \\
\text { EMERGING MARKETS } \\
\text { Available at http://jurnal.uii.ac.id/index.php/jep }\end{array}$ \\
\hline
\end{tabular}

\title{
Optimizing the role of tax auditor in attempt to achieve tax revenue target
}

\author{
Mawan Setianto ${ }^{1}$, Hamidah $^{2}$ \\ ${ }^{1,2}$ Faculty of Economics \& Business, University of Airlangga, Surabaya, Indonesia \\ e-mail: setianto20@gmail.com
}

Article Info

Article history:

Received : 9 November 2015

Accepted : 4 February 2016

Published: 1 April 2016

Keywords:

role theory, tax auditor, optimization, roles, role ambiguity

JEL Classification:

H2, H21, E62

DOI:

10.20885/ejem.vol8.iss1.art4

\begin{abstract}
This study aims to explain the role of Tax Auditor in KPP Madya Surabaya. This study uses a case study by collecting the data from Directorate General of Taxation official sources, either in KPP Madya Surabaya, Regional Office of Directorate General of Taxation East Java I, as well as the Directorate of Potency, Compliance, and Revenue. Researcher also conducted interviews with 12 informants consisting of Tax Auditor, Account Representative, Head of Office, as well as officials from the Directorate of Inspection and Billing. There are discrepancies between the expectations of stakeholders and what being understood/perceived and expected by the Tax Auditor in relation to the role that must be executed. This causes the Tax Auditor to experience a role ambiguity which disrupts the optimizing the implementation of the role. Things that still impede the implementation of the role of the Tax Auditor are: rejection of the Taxpayer; intervention both from inside and outside/difficult to implement the independence in appearance and independence in fact; both physically and psychologically threats; the unclear mutation policy; promotion criteria being implemented inconsistently; and databases that have not been accurate and reliable.
\end{abstract}

\begin{abstract}
Abstrak
Penelitian ini bertujuan untuk menjelaskan peran Auditor Pajak di KPP Madya Surabaya. Penelitian ini menggunakan studi kasus dengan mengumpulkan data dari Direktorat Jenderal sumber resmi Perpajakan, baik di KPP Madya Surabaya, Kantor Wilayah Direktorat Jenderal Pajak Jawa Timur I, serta Direktorat Potensi, Kepatuhan, dan Penerimaan. Peneliti melakukan wawancara dengan 12 informan yang terdiri dari Auditor Pajak, Account Representative, Kepala Kantor, serta para pejabat dari Direktorat Inspeksi dan Penagihan. Ada perbedaan antara harapan stakeholder dan apa yang dipahami/dirasakan dan diharapkan oleh Auditor Pajak sehubungan dengan peran yang harus dijalankan. Hal ini menyebabkan Auditor Pajak mengalami ambiguitas peran yang mengganggu pelaksanaan perannya. Hal-hal yang masih menghambat pelaksanaan peran Auditor Pajak adalah: penolakan terhadap Wajib Pajak; intervensi baik dari dalam dan luar/sulit untuk menerapkan independensi dalam penampilan dan kemandirian dalam kenyataannya; baik secara fisik dan psikologis ancaman; yang jelas mutasi kebijakan; kriteria promosi yang dilaksanakan tidak konsisten; dan database yang belum akurat dan terpercaya.
\end{abstract}

\section{Introduction}

Since implementing the tax reforms that began in 2002, the Directorate General of Taxation has a new organizational structure with emphasis more on function approach and not by type of tax. This era also marked by the presence of one new posi- tion, namely Account Representative (AR), which structurally lies on Section of Supervision and Consultation. The presence of $\mathrm{AR}$ in this organization structure is able to provide a substantial contribution and become a mainstay of the DGT (Directorate General of Taxation) in achieving revenue 
targets. On the other hand, the role of Tax Auditor who has greater authority toward the revenue contribution is being shifted and looked less than optimal. Besides, the data showed that the target of tax revenue from year to year is not always achieved.

Tax Office (KPP) Madya Surabaya, one of KPP in the Regional Office of Directorate General of Taxation (DGT) East Java $I$, is the one that experienced the condition. In the past 7 years, the revenue target is achieved only once (Table 1). Though KPP Madya Surabaya is what determines whether or not the tax revenue target achieved on DGT of East Java I. From 13 KPP in the area of DGT of East Java I, KPP Madya received the target allocation in range of $60 \%$ of the total target of the regional office; the remaining $40 \%$ is divided into other 12 KPP (Table 1). On the other hand, Table 1 shows that the amount of revenue target of extra effort surveillance (AR) from 2010 to 2015 is almost always higher than the examination (Auditor). Likewise, it also applies to the number of realization.

According to researcher, the above phenomenon is interesting to be studied. That Tax Auditor being not burdened with routine revenue target is easily understood because the nature of the examination is not constantly every year for all taxpayers. However, that the Tax Auditor who has more authorities than AR is burdened with extra effort revenue target that is lower than
$\mathrm{AR}$, requiring further exploration to understand it. How exactly does the concept of Tax Auditor role? How Theory of Role views DGT conditions in general and KPP Madya Surabaya in particular at this time? Is it in accordance with the position it bears, Auditor holds no less strategic role in securing tax revenue target? Auditor has the authority as stipulated in the Constitution that if managed properly will certainly make a positive contribution. With such authority, through examination, Tax Auditor can validate the financial statements of the taxpayer so that it can be determined how much tax should be paid by the taxpayer. Auditor also has the authority to propose to the Head of Office to issue a legal product in the form of Surat Ketetapan Pajak (SKP/Tax Assessment Letter) enforceable law to govern the taxpayer paying taxes by a certain amount. Auditor may also propose Examining the Evidence Starters if during the inspection there were indications the taxpayer has committed the crime of taxation.

Research on the importance of tax audit in securing the revenue of the country have been done in many times. One of the most effective methods to encourage the taxpayer to in improving their compliance voluntarily is tax auditing (Jin Kwon, 2006). This is in accordance with the opinion of Policy (2006), "enforcement activities should be combined with a commitment to taxpayer service".

Table 1: Comparison between extra effort of AR and Tax Examination in KPP Madya Surabaya 2010-2015

\begin{tabular}{ccccccc}
\hline \multicolumn{3}{c}{ Surveillance (AR) } & \multicolumn{2}{c}{ Examination (Auditor) } \\
\hline Year & Target & Realization & Percentage & Target & Realization & Percentage \\
\hline 2010 & $259.459,47$ & $635.387,13$ & $244,89 \%$ & $58.387,53$ & $47.451,77$ & $81,27 \%$ \\
2011 & $1.339 .874,72$ & $219.091,63$ & $16,35 \%$ & $111.637,49$ & $23.701,42$ & $21,23 \%$ \\
2012 & $75.814,74$ & $678.964,63$ & $895,56 \%$ & $116.748,35$ & $20.856,10$ & $17,86 \%$ \\
2013 & $325.966,00$ & $106.258,70$ & $32,60 \%$ & $73.213,86$ & $27.601,56$ & $37,70 \%$ \\
2014 & $597.488,25$ & $178.112,11$ & $29,81 \%$ & $180.789,80$ & $90.351,86$ & $49,98 \%$ \\
& $2.598 .603,18$ & $1.817 .814,21$ & $243,84 \%$ & $540.777,03$ & $209.962,71$ & $41,61 \%$ \\
2015 & $10.741 .098,75$ & & & $852.000,00$ & & \\
\hline
\end{tabular}

Source: DGT of East Java I Regional Office (2015) 
The result of Birskyte research (2008) mentions that the main tool used by the US tax authorities to minimize the tax gap and ensure a high level of tax compliance is tax auditing. The imposition of sanctions for taxpayers who had commit tax evasion as inspected, provides a deterrent effect for the taxpayer that has not been inspected. Poesoro (2015) also states that the high frequency tax audit and large penalties for tax evasion may decrease shadow economy.

While Martani Research (2011) on one of which concluded that companies in Indonesia tend to manage earnings by lowering the income even though contrary to the applicable provisions of the tax. Though the earnings management is one cause of the tax gap. Chan, Chau, and Leung (2013) wrote an article on the condition of tax inspection/investigation in China and Hong Kong, as well as discussed the tax inspection techniques used by the two countries in detecting the tax fraud. This research was motivated by rampant tax evasion phenomenon occurring particularly in China and Hong Kong and the world in general even in advance countries like the United States. They thought that any tax authorities in any country in the world is necessary to give more attention and implement strategies and specific policies to address the above phenomenon in order not to lose potential large tax that would undermine state revenue. They did research in China and Hong Kong to study how the situation or condition of the tax authorities in the country to face the tax evasion phenomenon.

The results showed that in China, tax inspection/investigation plays an important role in providing confidence regarding tax compliance and in order to protect or secure government revenue that implement self assessment system in the field of taxation. The government through the tax authorities applies the auditing system and policy that supports the achievement of the auditor role. Tax audit process starts with planning the annual tax audit by the tax authorities at all levels by considering the inspection needs and the available resources. Examination targets will be selected based on the results of the computer analysis, based on a specific percentage toward the number of taxpayer or random selection of which depends on the examination plan, also based on the information or data provided both at local and central level.

In Hong Kong, in recent years, IRD (Hong Kong tax authorities) expands the resource tax inspection/investigation with the aim: (1) encourage tax compliance; (2) educate the public taxpayers; (3) fight against tax evasion; (4) provide punishment for non-compliance behavior. In addition to that, IRD also periodically reviews to the effectiveness of the fight against tax evasion and tax avoidance by monitoring the performance of FAIU (Field Audit and Investigation Unit of IRD) through the following steps: (1) make effective use of information technology and strengthen the relationship between FAIU and other units in improving the efficiency of risk management of tax evasion and tax avoidance; (2) adjusting the criteria to identify cases of audit in response to changes in the social environment and business practices as well as handle high-risk cases; (3) strengthen the on the job training for Auditors and to improve the professional skills, practical experience, expertise to conduct investigations, through the rotation of position and participation in seminars, training, etc both locally and internationally.

Research using the framework of the role theory was done by Tan (2014) which examined the working relationship between the Tax Practitioners (Consultant) with the taxpayer (Client). This study aimed to show that the attitude and behavior of the taxpayer which is also influenced by the interaction with tax consultants, family, friends, and so on. Tan (2014) explained that the issue of tax compliance 
is a complex thing of which one aspect is the relationship between the taxpayer and the tax consultant.

To understand and analyze the relationship, Tan (2014) presented a role model between the Tax Consultant and the Taxpayer, namely Role Episode Method (REM). There is a reciprocal process that could either repeatedly or just once in the form of action and reaction between the Taxpayer and the Tax Practitioners related to the expected role given by the Tax Practitioners towards the Taxpayers. When interacting for the first time, the Taxpayer conveys expectation to the Tax Practitioner. If the Tax Practitioner immediately gives a positive response, it will create the role of Tax Practitioner to the taxpayer in just one action and reaction. But if Practitioners Tax respond negatively (e.g. due to demand Taxpayer toward the role of Tax Practitioners is to minimize tax payments by breaking the rules, and this is contrary to the values believed by Tax Practitioner), then there will be a process of action and subsequent reaction until both sides reached agreement on the role that will be run by the Tax Practitioners. In this process, each party will take a stand based on various considerations.

According to Solomon, Surprenant, Czepiel, and Gutman (1985), role theory is a theory which is a blend of various theories, orientations, and disciplines. The term "role" is taken from the world of theater. In the theater, an actor must play as a particular character and in his position as such, he is expected to behave in a particular way. Humans as social beings cannot live alone because there is a sense of interdependence with each other. In social life, humans occupied diverse functions, as a leader, a subordinate, government officials, ordinary community members, and so on. For what to be and who to be is depending on the surrounding environment or to whom he/she associated.
According to the role theory in its study towards the human relations, in a social interaction there are already existing scenarios or roles that had been developed by the community, that govern what and how everyone in his/her social role. For example, people who gathered somewhere in great numbers later referred to the community, the community then appoint a leader, for example, the Chairman of RT, which helps maintain and guide the community. Later in the larger scope of the state, appointed a president with a role that is set by the communities themselves. So in other words it is written that how to be a president, how to be a governor, how to be a teacher, how to be a student. Likewise, it is been written that the role of what should be done by the husband, wife, father, mother, child, and so on.

According to the role theory, if someone obeys the scenario, then his/her life will be harmonious, but if he/she violates the scenario, then he will be booed by the "audience" and reprimanded by the "director". For examples in this reform era, when a leader or a president who violates the scenario or her role will be demonstrated/protested by the public. Then it also goes to political life between countries or in the international community, as we can see from the role theory that is based on political analysis.

Role Theory views the organization as an open system, a system of roles; it consists of continuing, interdependent cycles of behavior, related in terms of their contribution to a joint product. Role Theory defines role ambiguity as occurring when it is unclear what is expected and whose expectations shall be met. Role Theory defines role conflict as occurring when two (or more) sets of pressure cannot be simultaneously served "(Kahn, Wolfe, Quinn, Snoek, \& Rosenthal, 1964). 


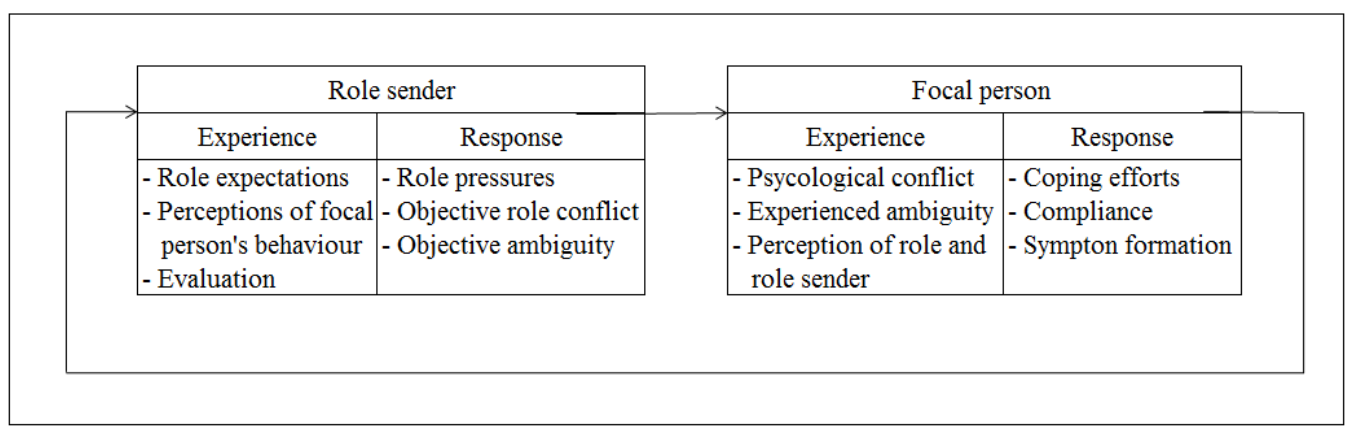

Source: (Kahn et al., 1964)

Figure 1: Episode Role Model

As shown in Figure 1, each box represents an event that forms an episode role. Expectations or pressures described above is sent to the focal person and form a new experience for the focal person. This experience has two typical: perceptual and cognitive aspects. The reaction of the focal person is determined by his experiences during this time. Focal person is also a selfsender because they also have a conception of their work and set of attitudes and beliefs about what should and what should not do in that position. They have an awareness of what behavior would fulfill their responsibility and take him so successful in his job. Through a long process of education and training, they have a selfidentity that motivate them to defend the values attached to their identity. "(Kahn et al., 1964, p. 17)

When the demands are forcing his role, focal person may fight toward the sender role request and result in the emergence of role conflict. Focal person may respond to the role conflict in several ways. A simple example, when they found out that they cannot realistically meet the expectations of the role sender, they will convince the role sender to be willing to change or modify the request could not be fulfilled as such (Kahn et al., 1964, p. 29). Or other possibilities, they refuse or avoid the role sender. Role conflict, as mentioned in the literature on organizational behavior and theory, can not be taken lightly as it can lead to severe consequences such as employees to experience stress or resign.

In Kahn models, role episode is drawn from a continuous spinning process: focal person is submitting feedback to the sender role, in order to transform the requests made to them. The demands of the role that will be sent next depends on the evaluation conducted by role sender on the response of focal person. Then a new episode will occur. As mentioned by Kahn et al. (1964), the whole process does not take place in a closed condition; expectations or behaviors shaped by additional factors such as organizational characteristics, personality, and interpersonal relationships between the role sender and the focal person. (Tan, 2014)

Furthermore, in $1978 \mathrm{Katz}$ along Kahn developed the role theory by clarifying the REM process which was released by Kahn in 1964. The REM process that has been developed can be seen in Figure 2 below.

Organizational factors (circle E) in Figure 2 represents a circuit of several variables. Arrows 3 states the relationship between the variables organizations with role expectations that are owned and sent by the role sender to the focal person. While the attributes of the person (circle F) refers to all of the variables that describe the tendency of individuals to behave in accordance with the goals and values, preferences to survive, sensitivity, and fears. Several factors influence the role episode in several ways. First, some innate self of a person is likely to 
cause or facilitate evaluation and behavior of the role sender (arrow 4). Second, the same message is sent can be understood differently by different people; therefore, acts as a personality factor of conditioning variables in the relationship between the message that was sent and the message received (arrow 5). Last, the role behavior has an influence on personality (arrows 6). A simple hypothesis that we are what we do, and otherwise we would not be what we are not doing. Someone who wants to play the role as a submissive, will not be able to run for long periods without personality changes as a consequence. Most of a person's ability will be lost if not trained.

Relations between individuals (circle G) meets the parallel function as described above and sent to the focal person at special times depending on the quality level of the relationship between a person and members of role-sets (arrows 7). Focal person will interpret differently the hope that is sent in a role-set, depending on the interpersonal relationships with the role sender (arrows 8). Finally, the behavior of the focal person gives the feedback and the effect on interpersonal relationships with members of role-sets (arrows 9). (Katz, 1978)

Supposedly, the examination is a package with self-assessment system. In accordance with the self-assessment system adopted by the tax authorities in Indonesia, the Taxpayer must calculate, estimate, deposit and report tax obligations by themselves. The result of the calculation of the taxpayer is considered correct for a while until being examined or until the expiration date. This means that if it is not being examined until the time of expiry, the Taxpayer should obtain legal certainty on the tax status of truth. Though the calculation carried out by the taxpayer could be wrong, whether intentionally or not. If the number of the counting and reporting of the taxpayer are correct, it does not matter as no one being loss. But if the calculation is wrong, then the country loses because there is an undefined potential income of the country. Therefore, the purpose of this study is:

1) To understand and to explain how the role of Tax Auditor in KPP Madya Surabaya, seen from the viewpoint of Role Theory.

2) To find out how to optimize the role of Tax Auditor in KPP Madya Surabaya.

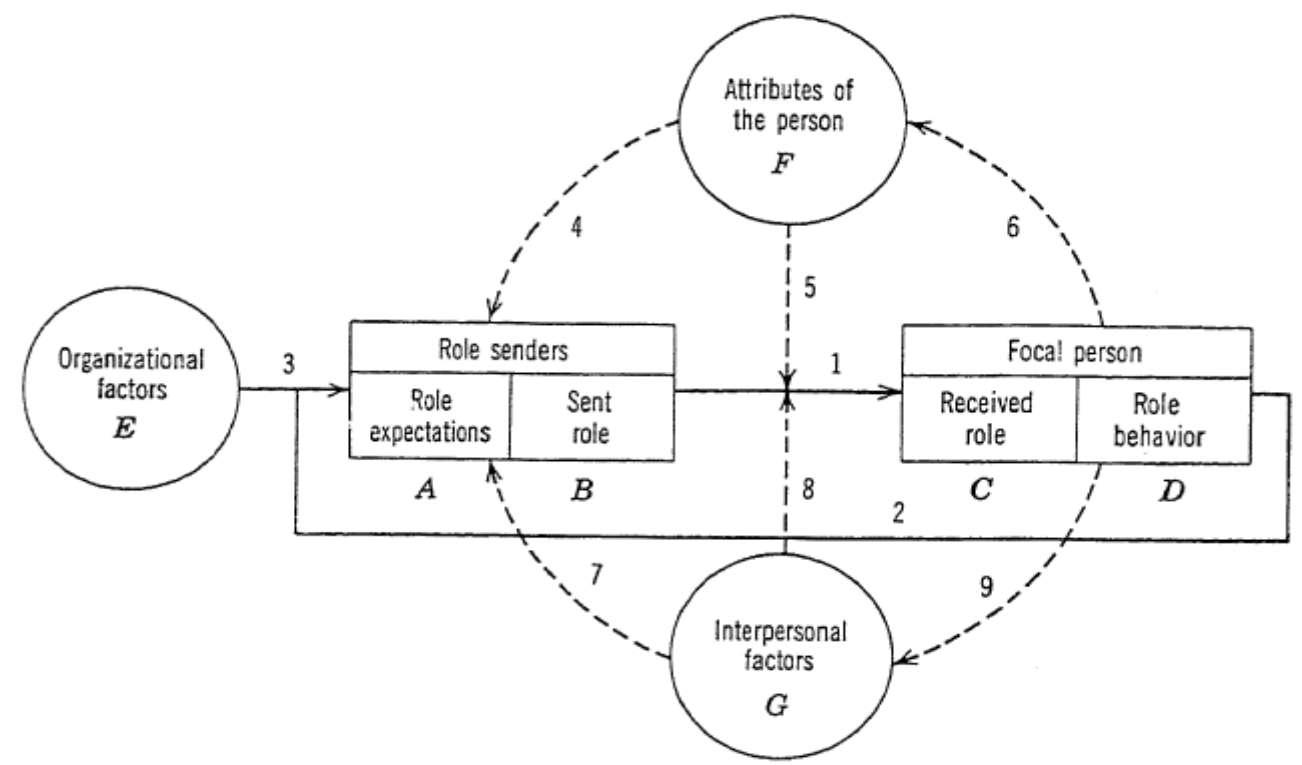

Source: Katz (1978)

Figure 2: A Theoretical models of factors Involved in the taking of organizational roles 


\section{Methods}

This research was conducted in the interpretive paradigm and used a qualitative approach in the form of a case study on KPP Madya Surabaya. Interpretive is chosen in this study because it is based on an understanding that the interpretive paradigm aims to understand, and (to interpret) so that the purpose of research that aims to understand the role of the tax auditor in a community or organization can be achieved. It can be accomplished because the interpretive paradigm emphasizes the researcher's interpretation of a social reality so that the results achieved more depth and the researcher has a wide space to interpret an object studied.

Case study is an empirical inquiry that investigates this phenomenon in the context of real life, when the boundaries between phenomenon and context does not appear explicitly or clearly and use multiple sources of evidence. As noted by Willis $(2007$, p. 240$)$, there are several advantages to be received by using case studies, among others: 1) allowing us to obtain data that is detailed and complete in authentic conditions; 2) case study is comprehensive so that it supports the idea of what we want to know about human behavior and can gain the best understanding on the experience of living in a social context; 3 ) in contrast to experimental studies, case studies can be done without hypothesis drawn up in advance. With the analysis and recommendations on the research that uses the case study, the related institutions, especially decision and policy makers, is expected to take better decisions in the future if they met with a similar case.

According to Yin $(2003$, p. 85), the sources of data that are commonly used in researching the case studies include: documentation, archival records (records/data comparison), interviews, direct observation, participant-observation (observation by involving the researcher himself) and physical artifacts (collect physical evidence). In this study, researchers used the documentation, archival records, direct observation and interviews to collect the data.

Documentation is used by researcher with collecting or obtaining documents such as letters, official memos, Memorandum of Understanding (MoU), reports of progress/achievements (progress report) and so on. The documents data sources which obtained directly from the company serves to reinforce and enlarge the evidence obtained from other sources (Yin, 2003, p. $87)$. Documents are also useful to verify the spelling and pronunciation of the name or title of the organization, making it easier to prepare interview questions and more familiar with the technical terms related to the site where the case study carried out.

Archival report or the company record is any written or recorded statement prepared by or for an individual or organization for the purpose of proving an event or provide notes for example diaries, speeches, minutes of meetings, service records, budgets, maps, charts and editorials. The documents that will be used as material analysis in this study include:

1. The regulations related to the examination (the Constitution, Decree of the Minister of Finance, Regulation of Ministry of Finance, Decree of the Director General of Taxation, Regulation of the Director General of Taxation, Circular of the Director General of Taxation)

2. The Policies related to the examination (Official Memos of the Head of Office and of such made by the Head of Office, Minutes of Meetings)

3. Document of the results of examination process which can be seen in Aplikasi Laporan Pemeriksaan Pajak (ALPP/Application of Tax Examination Report)

Direct observations was conducted by researcher toward the examination process performed by the tax auditor by observing the examination activities, especially undertaken in the office. The obser- 
vations are recorded in a form that has been prepared and will be used to cross-test equipment (triangulation) with information and data obtained from other data sources.

Interview plays an important role in gathering information for a case study because the interview allows researchers to record opinions, feelings, and emotions of the participants in relation to the phenomenon being studied (Yin, 2003, p. 89). This study using semi-structured interviews to obtain complete information as possible from the informants. The informant is a person with extensive knowledge of the data, information, or facts of an object of research (Bungin, 2005, p. 108). Therefore, informants are deliberately chosen to provide information that might not be provided by other informants. The informants of this research are Tax Auditors (7), Head of KPP Madya Surabaya (1), Account Representatives (3), and officials from the Directorate of Investigation and Billing of the DGT Central Office (1). Informants profile is as listed in Table 2.

Tax Auditors were selected as one of the informants because they are employees who perform the role of Tax Audit conducting an examination toward the tax- payer. They are people who feel how bittersweet role as Tax Auditor. They also know the things about the barriers, things that support them to perform their role, as well as have the expectations of the role concept as what would be mandated by the institutions to them in the future.

Account Representatives were selected as one of the informants because they are the highest fiduciary towards achieving the target of tax revenue. The most portion of the tax revenue target is charged to them. Failure or shortageoptimal implementation of the Tax Audit roles in addition to the impact on the institution will also impact on the increased demand of harder work toward AR. In addition, AR is also considered by researchers representing DGT employees other than Tax Auditor that also have expectations of the role to be performed by the Tax Auditor. According Soekanto (1990), in an organization, each member organization beside hold their own roles also have expectations of the role to be performed by others. Thus, DGT employees outside the Tax Auditor should also have expectations of the Tax Auditor for the role he had to do.

Table 2: List of Research Informants

\begin{tabular}{|c|c|c|c|c|}
\hline No. & Name Reference & Gender & Position & Length of Work in DJP \\
\hline 1. & Informant 1 & Male & Auditor Team Member & 19 Years \\
\hline 2. & Informant 2 & Female & Auditor Team Member & 10 Years \\
\hline 3. & Informant 3 & Male & Auditor Team Leader & 20 Years \\
\hline 4. & Informant 4 & Male & Auditor Team Member & 20 Years \\
\hline 5. & Informant 5 & Male & Auditor Team Leader & 15 Years \\
\hline 6. & Informant 6 & Male & Account Representative & 21 Years \\
\hline 7. & Informant 7 & Male & Account Representative & 16 Years \\
\hline 8. & Informant 8 & Male & Account Representative & 19 Years \\
\hline 9. & Informant 9 & Female & Supervisor & 25 Years \\
\hline 10. & Informant 10 & Female & Supervisor & 21 Years \\
\hline 11. & Informant 11 & Male & $\begin{array}{l}\text { Officials from the Directo- } \\
\text { rate of Investigation and } \\
\text { Billing }\end{array}$ & 24 Years \\
\hline 12. & Informant 12 & Male & Head of Office & 20 Years \\
\hline
\end{tabular}


Head of KPP Madya Surabaya was selected as one informant as the manager of the Tax Auditor. Head of KPP Madya Surabaya is also an interested party to the success of the role undertaken by the Tax Auditor of KPP Madya Surabaya. The failure of Tax Auditor in performing his role will contribute also to the failure of its businesses. In addition, the Head of KPP Madya Surabaya course also have expectations of the role to be performed by the Tax Auditor related to the core business of the organization as a tax collector agency.

Officials at the Directorate of Inspection and Billing (Directorate P2) was selected as one of the informants because the Directorate P2 is the second echelon unit in the DGT that functionally supervises the Official Functional Group of Tax Auditor. Directorate P2 task is to formulate and implement the technical policy and standardization in the field of tax examination and collection. On the other hand, the functions of the Directorate P2 are such as: 1). prepare policy formulation in the field of tax examination and collection; 2). prepare the implementation of policies in the field of tax examination and collection; 3 ). prepare the drafting of norms, standards, procedures and criteria in the field of tax examination and collection; 4). prepare in providing technical guidance and evaluation in the field of tax examination and collection; 5). carry out administrative affairs of the directorate.

In accordance with the concept of Role Theory presented by Kahn et al. (1964) through Episode Role Model, the themes analyzed in this study include:

1. The current role of Tax Auditor as seen from the perspective of the Role Theory

a) Understanding of the actors toward the role of Tax Auditor

b) Factors affecting the Tax Auditor in performing their duties and roles

c) Performance of Tax Auditor

2. The hopes of the role sender, the surroundings and the focal person

\section{Result and Discussion}

\section{Understanding of the actors toward the role of tax auditor}

According Soekanto (1990, p. 268), role is a dynamic aspect of the position (status) that when someone is exercising its rights and obligations in accordance with the position so he/she is running a role. While the role of the social sciences means a function that is performed when a person occupying a particular position. A person can play function because of the position he/she held. A person is said to play the role when he/she is running the rights and obligations that are part of the status he/she bears.

Tax Auditor as one of the positions in a formal organization called DGT, also has a role in the organization. Individuals who served as Tax Auditor assume the role as a Tax Auditor. According Soekanto (1990, p. 268) above, if such individuals exercise their rights and obligations as a Tax Audit properly, it can be said that they had been carrying out their role. But if you follow the social sciences then the Tax Audit is said to have played its role if it functions in the organization DGT. Hence, the keywords are the rights, obligations and functions.

Rights, obligations, and functions of the Tax Auditor in DGT institution is already contained in the Constitution No. 6 of 1983 as amended by the Constitution No. 16 of 2009 on General Provisions and Tax Procedures. Article 29 paragraph (1) states "The Director General of Taxation is authorized to conduct an audit to verify compliance on fulfillment of tax obligations of Taxpayers and for other purposes in order to implement the provisions of the tax legislation".

On the other hand, Article 29 paragraph (2) states "For the purpose of the examination, auditor should have the auditor identification and equipped with Investigation Order and present it to the taxpayer." Explanation of paragraph (2) states that the 
examination is carried out by auditor who are clearly identified. Auditor should have got enough technical education and skills as a Tax Auditor.

From these explanations it can be concluded that the DGT authority to conduct an audit to verify compliance fulfillment of tax obligations and for other purposes in order to implement the provisions of the tax legislation is run by the Tax Auditor. In other words, the function of Tax Auditor in the organization is run DJP authority to verify compliance on fulfillment of tax obligations and for other purposes in order to implement the provisions of the tax legislation. This is in line with the opinion of Levinson on Soekanto (1990) that the role includes of norms associated with the position or one's place in society is a series of regulations that guide a person in social life.

While the right or authority of the Tax Auditor as contained in the Regulation of Minister of Finance No. 17/PMK.03/2013. Article 11 regulates the obligation Tax Auditor, as follows: 1). submit a letter of examination notification (field examination) or call letter (office examination) to the Taxpayer; 2) show Tax Auditor Identification and Examination Order; 3). show a letter containing the changes to the Tax Auditor Team to the Taxpayer if Tax Auditor team composition changes; 4) conduct meeting with the Taxpayer in order to provide an explanation of: the reasons and purposes of the examination, the rights and obligations of the taxpayer during and after the implementation of the examination, the right Taxpayer to call for discussion with Quality Assurance Team of Examination in the event of the examination result that have not been agreed between Tax Auditor by the Taxpayer at the time of Final Discussion of Examination Results, obligations of the Taxpayer to meet the demand for books, records and/or documents that became the basis of the books or records and other documents, which will be borrowed from the Taxpayer; 5) pour the results of the meeting with the taxpayer in the form of the minutes of the meeting results; 6) submit Surat Pemberitahuan Hasil Pemeriksaan (SPHP/Notice of Examination); 7) entitle the right to present to the Taxpayer on Final Discussion of Examination Results at a predetermined time; 8). deliver the examination questionnaires to the Taxpayer; 9). provide guidance to Taxpayer in meeting their tax obligations in accordance with the provisions of tax legislation to submit suggestions in writing; 10). return the books or records, documents borrowed from the Taxpayer; 11). conceal to others who are not entitled to of everything that is known or disclosed to the Taxpayer in the examination.

Article 12 regulates the authority, such as: 1). view/borrow books or other records and documents; 2). access and/or download data that is managed electronically; 3 ). enter and inspect a place or space, allegedly used to store books/records/documents/money/goods; 4). ask the Taxpayer to provide assistance in order to complete the examination; 5). seal a place or a particular space and movable and/or immovable goods; 7). Request an oral and/or written from the Taxpayer; 8). request information and/or evidence from third parties that have a relationship with the Taxpayer through the head of Unit Pelaksana Pemeriksaan (UP2/Examination Implementation Unit).

For office examination, the authorities of Tax Auditor are as follows: 1). call the Taxpayer to come to the DGT office; $2)$. view/borrow books or other records and documents; 3). ask taxpayers to provide assistance in order to complete the examination; 4). Request an oral and/or written from the taxpayer; 5). borrow examination paper made by Public Accountant through the Taxpayer, 6). request information and/or evidence from third parties that have 
a relationship with the Taxpayer through the Head of UP2.

However, in practice, the institution itself is less assertive in positioning the role of Tax Auditor. Functioning as an officer to examine the tax compliance as well as examination for other purposes is not doubtful or disputed again. But if the function has implications for the imposition of the tax revenue target, it still contains obscurity until today. Until 2013, achieving the target of extra effort is still one of the Key Performance Indicators (KPI) for the Tax Auditor. However, since 2014 until now achieving the target of extra effort no longer be one of the KPIs for Tax Auditor even though still burdened with extra effort revenue target.

It seems inseparable from the development of two opinions on how the role of Tax Auditor should be. Some employees in DGT besides the inspectors generally found that in running their role as an officer to examine the tax compliance as well as carry out the checkings for other purposes, the examiner is still burdened with the tax revenue target. The first reason is that the Tax Auditor has the authority which is not possessed by other employees of the DJP. The second reason is that the Tax Auditor is an educated human resource with specialized expertise that is not retained by other employees of the DJP. The third reason is that the Tax Auditor receives take home pay which is relatively higher than other employees of the DJP. As a formal social community, it will be a natural thing if a coworker or employee who occupies other positions has expectations of the functions / roles taken by the tax auditor. According to Kahn et al. (1964, p. 26):

"Role set consist of different people (term role senders) with whom the focal person has contact. Role senders have a stake in the focal person performance as they can benefit or be disadvantaged by it. They may also be dependent on the focal person's performance as they may require it to perform their own task. Accordingly, they develop beliefs and attitudes about what the focal person should or should not do.The prescriptions and proscriptions held by members of a role set are termed role expectations and they represent the standard for evaluating the performance of focal person."

The Proccess can be performed in the figure 3 below.

In the context of this study, role senders are the personage such as the Head Office and AR while the focal person is a Tax Auditor. The Head Office and AR have certain expectations upon the role of the Tax Auditor in the organization. The expectation will always be evaluated based on the perception on the behavior of Tax Auditors and an evaluation of the response they submitted. Role senders will send back a response to the Tax Auditor of the expected role and whether the fulfilled or unfulfilled role will give a profit or a loss for them.

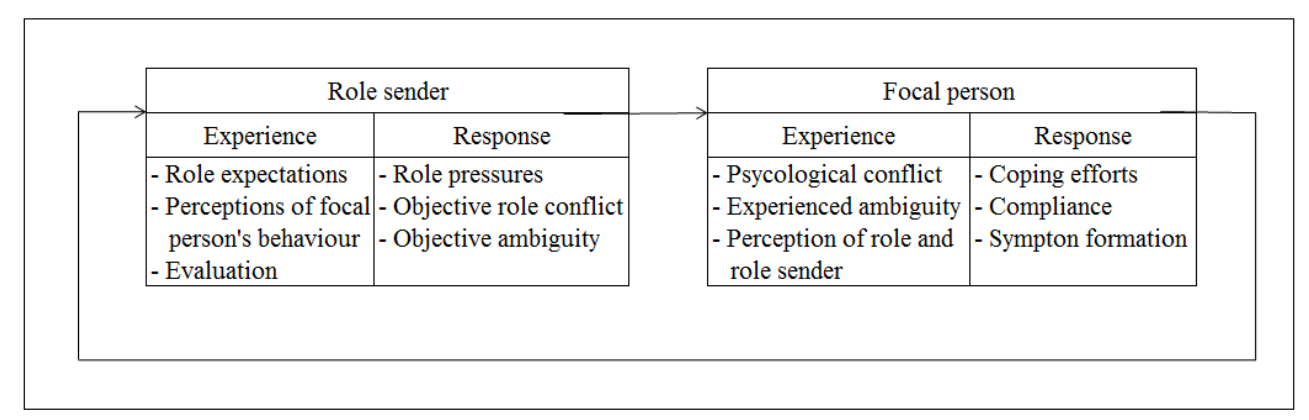

Souce: Kahn (1964)

Figure 3: Role Episode Model 


\section{The role of Tax Auditor according to role senders}

Informant 7 expects that the extra effort target would remain the examiner's KPI, so the auditor will be more motivated to perform optimally.

(If it is urgent in all offices at the first place, it (extra effort target) should be one of the KPI's achievements. Because if it's only SP2, well, there will be no motivation to achieve the money value. Database of DGT is now better than several years ago. The fellow auditors received extraordinary education to become ones. The take home pay is also remarkable. They should be more creative in exploring the data and potential, with all the limitations exist. I'm sure, many can make remarkable achievements inspite of the limited conditions. So, blaming the database is not quite right.")

Informant 8 has a greater expectation, that the revenue targets remains to be the responsibility of Tax Auditors and expect them to work more creatively and improve the cooperation with AR:

"Targets still ought to be their responsibility ... due to the proportion. The auditors have to keep cooperating with $\mathrm{AR}$ in auditing. And not only use our data but also creatively search data from other sources. "

On the other side, informant 12 , as the Head of the Office stated his opinion $\mathrm{s}$ follows:

As one of the managers of KPI, I believe that anyone who works in DGT must have a target. There should be measurements. My hope, the auditor still have target as their responsibility since collecting tax is the responsibility of every single person in DGT. Moreover, the audi- tors have the most powerful forces in facing the taxpayer. "

The role senders generally have high expectations on Tax Auditor. They hope Tax Auditors, who have great authority, adequate education and training, qualified expertise, have access to view the AR's data through approweb or applications developed in madya, and supported by relatively large take home pay, can contribute to the office revenue target which is getting bigger and are able to become one of the play maker of the DGT in carrying out the mandate to achieve the target of tax revenue which is increasing every year. Therefore, it is necessary to include the extra effort target as Tax Auditor's KPI so they will be more motivated and work more seriously to reach the target.

Meanwhile, Tax Auditor as focal person has different opinion. Almost all informants from Auditor group think that their role is only as law enforcement executor and serve taxpayer and not as main personels to achieve tax revenue target. Informant 1 stated:

"What is called as auditing is only checking the compliance. If it is foundng is done properly, then it is done. But if a shortcoming is proven, then it has to be billed in auditing that everythi. Indeed, we do all the testing, distribution and all related activities. We tried to get it proven. If it's appropriate, it's fair, then it's done. We will not search for mistakes. So, when all is executed in accordance with the procedures and standards, that would have been sufficient. It would not be relevant if fresh money becomes our responsibility because the objective of auditing itself is not to pursue the revenue. "

Similar to the opinion of informant 1, informant 2 also argued that the Tax Au- 
ditor's role is to conduct law enforcement, compliance testing, and it is not appropriate if revenue target becomes the responsibility.

"It is true that the responsibility is to enforce the law. If taxpayer has been obedient, so be it. compliance testing was listed in SP2. So if you've been obedient, fine, if not, you should reported it. Regarding the revenue target, I personally disagree. Because auditor only to test compliance ..."

Informant 4 has similar opinion to informant 1 and 2 . He believes that auditor's role is as executor and law enforcement, but not revenue target.

\begin{abstract}
"Kalau menurut kami pemeriksa posisinya itu hanya eksekutor saja mas. Jadi kalau dimaksimalkan untuk mencapai target penerimaan, itu menurut saya tidak pas."

"We think our position is as axcutor only. So I think it's irrelevant to expect us to fulfill revenue target."
\end{abstract}

The first episode of the establishment of Tax Auditor's role according to REM made by Kahn (1964) is the delivery of role expectation from stakeholders to the Tax Auditor. From the interview above, it can be seen that there are discrepancies between the expectations of stakeholders with Tax Auditor's understanding/ perception upon the later's role. Katz (1978) mentioned that in the process of establishing a role, there are 3 possible misunderstandings. The first is role senders misunderstanding in applying regulations or concept of a role from the organization. The second is focal person misunderstanding in understanding the role sent by role senders. The third is role senders misunderstanding on focal person responses.

\section{Factors influencing Auditors in under- taking their duty and role}

Observing the stories of the informants, it can be found that working as a Tax Audit is vibrant, sometimes dark sometimes light. Sometimes gloomy somethimes bright. Settling at the front door of the taxpayer, called by 'strong figures' to ask for some 'help', crowding with taxpayer, their family is threatened, threatened with being reported, complained of the offense do anything unpleasant, loan documents are not given, disconcerted by taxpayer's response letter about a tax case which is opposite to the auditor's opinion and a lot more.

"There is an intervention from a particular party (authority or other important people) by giving us a call. 'I am X, please help taxpayer z', said informant 10.

"If taxpayer is an important person, they usually have more strong parties behind. It is also hard for us to see them. Meanwhile, we have no one behind us," states informant 2 .

The most common thing and happens to most of DGT employee is being away from family. Each indiviuals may have different response in facing the situation. Yet, it must be admitted that the condition is becoming the concern since it may influence the employee's performance. The things experienced when they are on duty as tax auditor will affect their expectations upon the roles to be given in future time.

When the researcher asked what support they have to undertake the duty as Tax Auditor, the informants' answers were as follors: support from family, support from upper position, support from colleagues, office facilities, stigmas which is getting more positive, and sufficient take home pay. Family support is very important since being mutated nationally is one of consequences as a tax officer, so there is 
always possibility to be away from the family. Family awareness of the condition will of course be a great support to motivate the officers to work in tranquility, wherever they are placed.

Support from the superior is no less important. The superiors are people to whom they mostly have interaction at work. Superiors have expectations upon the auditors that often causes distress in the attemp of fulfilling the targets set. However, superiors must also motivate, encourage, assist, coach and even secure in case any threat occurs during the completion of the work.

Besides the two above, Auditors consider colleagues' support is plentiful. Fellow AR has performed their function very well, like in giving advice on special audit or providing data and informations when audit on taxpayer is made. Colleagues from other sections such as Data and Information Processing sections, Services Section, Inspection Section, Billing Section, and General affair sub section are supportive enough in providing data or facilities to support the audit proccess.

Office facilities are also considered decent and support the audit activities. Office facilities here refer to official vehicles, computers, printers, supplies, representative and conducive room, and other facilities.

Another thing that is supportive to the audit activities is the stigma in the society which has been improving. The auditor felt that the society's stigma used to be negatif, possibly because of some deviated behavior of the individual when auditing. The image of the Auditors is now getting better because ever since the modernization of the DGT, violations of the code of conduct by an employee will achieve strict sanctions. This, to some extent, makes Auditor hesitate to do less commendable behavior and disruptive actions against employee code of ethics.

Furthermore, take home pay is becoming one aspect uplifting the role of auditor. Since Since Presidential Regulation
No. 372015 on Employee Benefit Performance in the Directorate General of Taxation Environment was released, Tax Auditor's take home pay is increased quite significantly, even higher than executive employees (non functional). Although it could cause resentment amongst the internal colleagues, but the increase is able to rally motivation of the Auditors.

\section{The performance of tax auditor}

Opinions are varying among informants, which is obviously because each informant is in different conditions. The understanding of the unclear and obscure concept of the role of auditors in the institutions also causes them to experience confusion in assessing whether the roles they are running is optimal or not. In current conditions, those who carry limitations and shortcomings in some respects think that they are doing their best. However, it will contribute to more positive role and performance in the future if some matters and obstacles are resolved. Generally they recognize that their role and performance can be improved.

Informant 12 stated that one of the reasons why the implementation of the Tax Auditor's role is not optimal is because of the tight routine checkings schedule which leads to less time to do a special inspection. Whereas according to informant 12 , a routine checking is relatively less potential than the special inspection.

Considering the criteria of routine checkings and special checking which is in accordance to Circular letter of the Director General of Tax No. SE-28 / PJ / 2013 dated June $11^{\text {th }}, 2013$ on Audit Policy, the researcher can understand what is conveyed by informant 12 , that routine checking is relatively less potential than special checking. Taxpayers in routine checkings criteria are those who are 'ready' to go through audit because they are well prepared into these criteria so big tax corrections are less likely found. While taxpayers in special checking criteria are very likely unaware of 
the audit undertaken so the possibility of a correction is larger. Therefore, if the roles of the Tax Auditors are to be optimized, they should have SP2 of taxpayer that generally meet the criteria for special checking.

Meanwhile, the achievements of Auditors of Medium Tax Office of Surabaya in 2014 according to Key Performance Indicator (IKU) are as in Table 3.

If we observe the table of achievements of KPI above, Tax Auditor's is number 6 , consisting of 6a-CP (actualization of audit completion percentage) and $6 \mathrm{~b}-\mathrm{N}$ (on time audit completion percentage). Of the collumns of Medium Tax Office of Surabaya's KPI, 'extra effort revenue realization percentage' is in red category, as well as 'checks completed on time percentage'. Meanwhile, the audit KPI of 'realization of audit completion percentage'is at yellow level. Red is when chievement index below $80 \%$, yellow is for achievement index level of $80 \%$ to below $100 \%$, and green is for achievement index of $100 \%$ up. Since it is still at red and yellow level, the performance of Medium Tax Office of Surabaya in 2014 is still not optimal.

Tabel 3:

NILAI KINERJA ORGANISASI (NKO)

NAMA UNIT PERIODE PELAPORAN
: Kantor Pelayanan Pajak Madya Surabaya : Tahun 2014

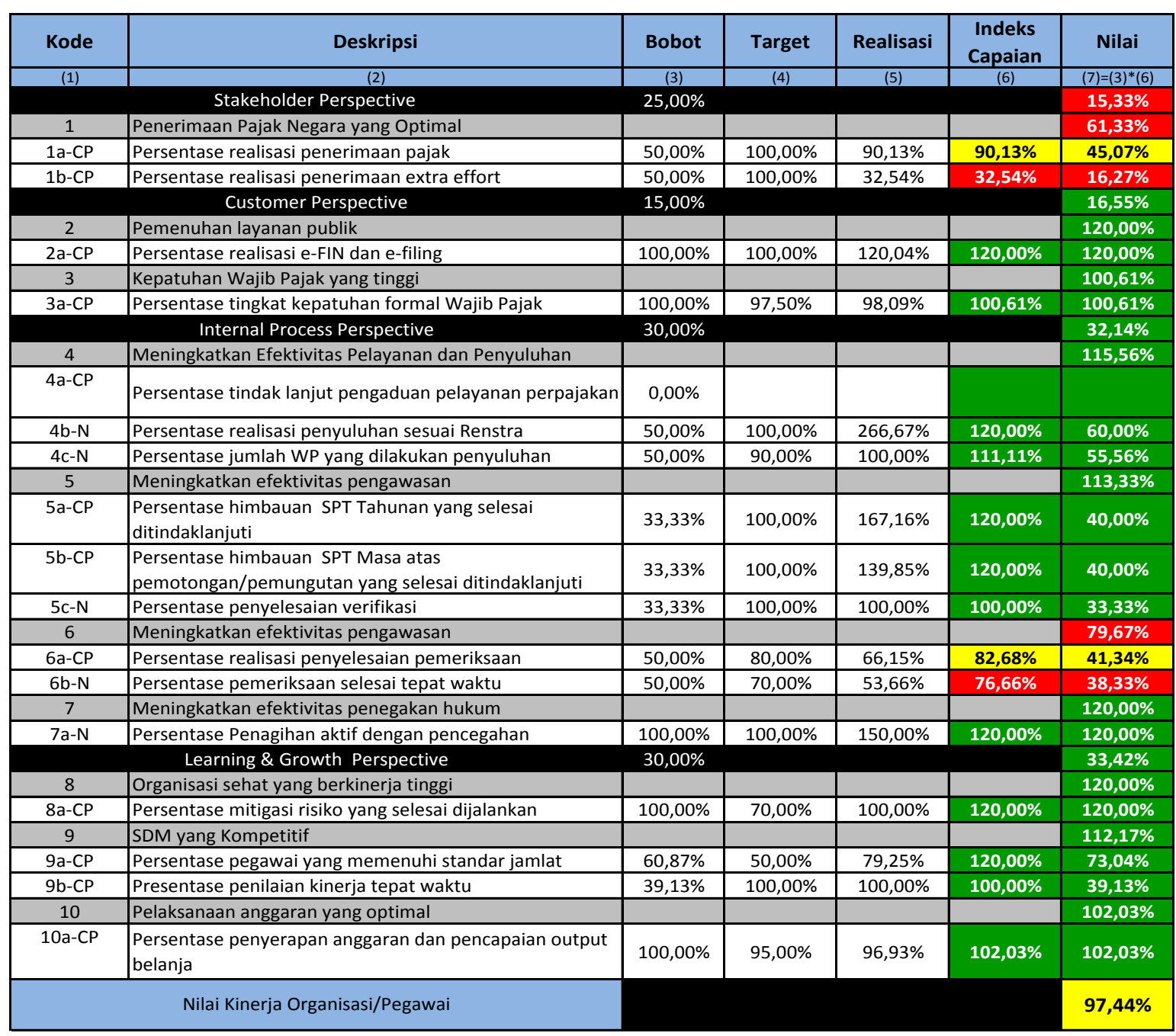

Source: Medium Tax Office of Surabaya (2015) 
The expectation of tax auditor, AR, head of medium tax office of Surabaya, and pejabat direktorat $\mathbf{P 2}$

Every member of a community devours hope, not to mention the Tax Auditor as a community member of DJP. They hope for reward commensurate with employee performance; clear, fair and transparent policies and patterns of mutation; more complete and accurate database; auditors' capabilities enhancement; clear and consistent promotion criteria; Examining an increasing number of human resources; and rules synchronization.

"targets should be encumbered with the given reward. The pattern of mutation is clarified. Administration should be nicer, the data must be accurate. Taxpayer transfer process between the KPPs should be monitored especially the database to make the migration perfect," informant 3's opinion.

Meanwhile, informant 4 expects institutions to facilitate Tax Auditor's capabilities enhancement, improve the promotional mutation pattern, improve promotion policy, as well as improving synergies between AR and the auditors.

"Institution must encourage the auditors' capability like the knowledge, skills, insight, and case experience. DJP is much better nowadays. Mutation pattern is getting better, but still needs improving. Only promotion is inconsistent. At the moment, the synergy between AR and the auditors in KPP Madya of Surabaya is fine though it can be improved. Sharing data to each other".

Informant 10 stated that one of the weaknesses of the DGT is the availability of data that is less accurate and reliable so that institutions should strengthen the database. Informant 10 also hoped that the in- stitution improve promotion-mutation policy as it was also expected by informants 4 .

"One of our weaknesses is in the data. So the institution must strengthen the database in the future to make it more accurate. There are many data from other institutions which are not completed. The clear mutation matters need to be improved as well, especially the pattern, from where to where".

In the other side, the expectations of AR are:

Informants 6 as AR stated that he hoped for increased synergy between the $\mathrm{AR}$ and the Auditors. It is also to produce more communicative performance in undertaking their role.

"Personally, it has been performed (supporting each other or having synergy with the auditors), the auditors consider or consult to AR in audit process. But some are not really communicative. DGT needs to arrange a better policy to improve the quantity and quality of the auditors".

Informant 7 hoped that the DGT becomes more independent institutions so that there will be no place for intervention, especially which are destructive for the existing order.

"Institutionally, I agree that in accordance with what has been outlined by the central office, about the independence. If it becomes a body, seems to me it would be great. What is already formulated at the central office has been good. The more independent, the better it will be, not much intervention. If it is still under the ministry, then there will be a lot of intervention. One rule is issued, then canceled. That our data access can be in accordance with the provisions in the KUP Act can be rea- 
lized, it would be much better. But the beauty of the provisions in the Act appears not as beautiful as the practice hahaha ..."

As for Informant 12, he hoped that 2016 is a year of law enforcement for the taxpayer, the headquarters could provide better screening policies, for instance by handing the checkings on unpotential taxpayer to to non-functional tax auditor.

"My hope is that 2016 is the year of law enforcement. So in this case the head office of the Directorate of Inspection and Billing must be able to provide direction to all function we have to really create law enforcement euphoria. Give them the task to perform inspection that do need depth, the potential ones. Let the small ones to be conducted by tax non functional auditors, yet remain under the supervision in each office. I also expect that the auditor is still burdened with the target since it is the responsibility of every person in the DGT. Moreover, the auditors has the most powerful forces in facing taxpayer."

Here are the advice from informant 11 for DGT to be stronger and more strategic in terms of its role:

"What I think, all the functions in the DGT was re-discussed by the leaders with the same vision, mission, and spirit. Do not highlight the personal ego. Next, there should be institution's allignments to all employees. Before the employee is proven guilty, do not judge. Create great cycle, auditors are returned to the khittah but it should also create a good oversight mechanism so that they do not mess around. Select potential taxpayer to be checked. I also hope the conditions will be improved in the future because I see the concept of Mr.Edi, the present Director of $\mathrm{P} 2$, is good, conceptual. He designed the examination to actually give deterrent effect. Meaning that if we only have around 4000 auditors, there will be three things to be considered to make the deterrent effect more clear. First is the selection of potential taxpayer. So the taxpayer being audited are those who are worth checking and potentially contribute to deterrent effect. Like who? If its is personal, then important people. If it is institutions, then perhaps instutions with bigger volume. Second is capacity building of the auditors as well as the attention to his career path. There is a plan to make make ongoing training from junior, senior, and so on. There will be some sort of higher career path. Why is it needed? Because for now, auditor's highest position is supervisor. Psychology it is not good for the employees. At the time they become supervisor, what is the motivation to do something better? Not much. Per01 is good enough, but the rules for it is limiting. For example, there are rules to be eselon 3 candidate, but the person must at least has been head of section for 5 years. Lately it is revised, to have become functional auditors for 10 years. From this, there is a tendention to have more regulation which is actualy revisions. So basically Per-01 is good, but the implementation is not as well as the written. And the third is regulation harmony. Sometimes the regulation of the auditors and other directorate are different. Verification, for example. It causes verification invalid. Sometimes it is then called nonfunctional auditors. But when the team is about to create, there is a problem with the SPPD, with the at- 
tendance, with the KPI, and etcetra. So the three are important. What is more important is the strategical planning. In this one, the position of the auditors is no longer in the family or law enforcement officer, but the inspection. It is somehow odd. Generally, auditors are the stepping stone of law enforcement. Whose idea is it is obscure. Now, the law enforcement officer is only as investigator and billing. But I am optimistic that it will be better in the future, regardless the improvement of the quantity of the human resources. But then again get back to the target. Then human resource management is still not good enough. The current conditions have not been ideal for creating a conducive working atmosphere, not only Examiner, but also AR, Services, are all like that. Especially with the unclear mutation pattern, payroll system which were all the same in every offices, this will lead to the tendency of employees to hide. He would not perform well. Because if he perform well, he will be moved and promoted to a distant place which is not his home base, with expensive living cost but the same salary with his friends in the previous homebase. Hopefully it will be better in the future. We still have hope. I see the DGT in recent years is designed to be loved by the people, by the taxpayer. Is the taxpayer being more obedient with more service from DGT or not? Good service is not a guarantee for an obedience. Why, because basically the taxpayer is hesitate to give away their wealth to the country without direct reward. It is unlike the condition when the taxpayer come to a service based institution like health care. They will willingly come back for better service inspite of the expense they should pay. According to the literature I studied, what makes people obedient to the taxtation institution is actually the other institutions' performance. For example when the national stability is increased. People will sincerely pay tax. The second is when the government run well. Then when the corruption is decreased. It will uplift people's obedience. Yet, even when the DGT serves very well, do this and that to improve its service, the change won't be significant. There is only one internal variable that will make the taxpayer obedient and it comes to the same result in every research. What is it? The more audit, the more obedient the taxpayer will be."

\section{Conclusion}

The creation process of the role of Tax Auditor as described in REM by Kahn et al. (1964) in the institution has not been completed. This is demonstrated by the reality of the actors understanding of the concept of Tax Auditors' role which is still different. The different understanding generally occurs between the Tax Auditors with the Stakeholders. Tax Auditors experience role ambiguity because of a lack of clarity between what is expected with the expectations to be met. Realization of KPI of KPP Madya Surabaya in 2014 showed that the performance of Tax Auditor has not reached the set target. This is one indicator that shows that the role of Tax Auditor in KPP Madya Surabaya is still not optimal.

In accordance with the theory of Role by Kahn et al. (1964) and Katz (1978), to make a role run optimally, the process of REM should be completed. REM process can be considered complete if each party, role sender and the focal person, in this case the Stakeholders and Tax Auditors, already understand the agreed 
role concept and accept the concept of mandated role.

1. In the condition that there are still some limitations, Tax Auditor should still try to perform its role as well as possible, including overcome the limitations of the institution database by creatively find other data independently, either field search or through the internet.

2 . In addition to the matters that still impede the optimization of the role of Tax Auditor, there are also those things that already supports, such as: employment (synergies) which are pretty good between functions or parts, enough take home pay, motivation and support of the leaders, also facilities and infrastructures.

All parties within the organization relating to Tax Auditor, the Stakeholders, sit together to redefine the concept of Tax Auditor's role in the organization. It aims to equalize the understanding of the concept of Tax Auditor's role so that role ambiguity and role conflict are not happening anymore, and to increase the synergies between the functions within the organization to realize the optimal role of Tax Auditor. If the selected decision is not giving the tax revenue target responsibility to Tax Auditor, then in addition to optimizing the function of watchman attitude which is now run by the Directorate of Internal Compliance and Transformation of Apparatus Resources, special function is also needed to form in the organization of which task is to assess whether an inspection had run optimally or not (supervisor performance). In the context of REM process, institutions need to consider the expectation and suggestion of tas auditors, which are:

1. Fix the bank data to make it more accurate and reliable.

Complete accurate and reliable bank data, are not only to assist in the supervision of the taxpayer, but also very important to support the law enforce- ment process so that the taxpayer will feel observed and concerned. This will increase compliance.

2. Apply the promotion criteria consistently.

Institutions need to fix promotion criteria for a Tax Auditor to make it more open, fair, and consistent. If there are specific policies that are exceptions to the general policy, it should be discussed openly with the Tax Auditor by taking into account feedback and complaints from them.

3. Minimize SP2 on unpotential taxpayer and maximize SP2 on the potential taxpayer.

Recognizing that one of the causes of less optimal role of Tax Auditor is because of the resources they have are less used if they do the inspection routine which is generally an audit of the less potential taxpayer. Therefore, their resources should be used for more potential taxpayer. To that end, a database owned by the DGT must be able to detect as early as possible the potential taxpayer.

4. Clarify and fix Promotion-mutation Policy.

DJP redefined mutation-promotion policies so that it becomes increasingly clear, fair, and transparent. Although there is no guarantee that policy improvement will satisfy all parties, it still need sincere and continuous efforts for a more clear, fair and transparent improvement.

5. Improve the legal protection system for the tax auditors when undertaking he role.

DGT also need to build a system that can protect both physically and legally to all employees in general and in particular to the Tax Auditor. This protection is required for working in the Directorate General of Taxes is a job that is unpopular, so vulnerable to the physical threat or legal claim. 
The phenomenon of extra effort revenue target composition, a tendency of not achieving the revenue target, and debate about the role of Tax Auditor happen in nearly all KPP throughout Indonesia, amounting to more than 300 units. This research was conducted only in one KPP chosen with a certain consideration. To obtain more accurate results and conclusions which can be described nationally, then future studies should take some KPP which are considered to represent every region in Indonesia as a research site or combining qualitative methods with quantitative methods (mix-method).

\section{References}

Birskyte, L. (2008). The Effect of IRS Audit Rate on State Individual Income Tax Compliance. (Doctoral Dissertation), Indiana University, Indianapolis. (3342195)

Bungin, B. (2005). Analisis Data Penelitian Kualitatif (pertama ed.). Jakarta: PT. Raja Grafindo Perkasa.

Chan, S., Chau, G., \& Leung, P. (2013). Tax Audit and Investigation in China and Hong Kong. International Tax Journal, 39(1), 31-49.

Jin Kwon, H. (2006). Mongolia: Reform of the Tax Audit System. Asia Pacific Tax Bulletin. APTB, 12(4), 341-348.

Kahn, R. L., Wolfe, D. M., Quinn, R. P., Snoek, J. D., \& Rosenthal, R. A. (1964). Organizational Stress: Studies in Role Conflict and Ambiguity: John Wiley \& Sons Inc.
Katz, D. K., R.L. (1978). The Social Psychology of Organizations: Wiley.

Martani, D. A., Yulianti; Fitriasari, Debby. (2011). Book-Tax Gap: Evidence from Indonesia. China-USA Business Review, 10, 278-284.

Poesoro, A. (2015). Narrowing Tax Gap: Cross Countries Experience. Tax Law Design and Policy Series, 0915.

Policy, U. S. D. o. T. O. o. T. (2006). A Comprehensive Strategy for Reducing The Tax Gap.

Soekanto, S. (1990). Sosiologi Suatu Pengantar (Edisi Baru Keempat ed.). Jakarta: PT RajaGrafindo Persada.

Solomon, M. R., Surprenant, C., Czepiel, J. A., \& Gutman, E. G. (1985). A role theory perspective on dyadic interactions: the service encounter. The Journal of Marketing, 49(1), 99111.

Tan, L. M. (2014). Understanding the Tax Practitioner-client Relationship: Using a Role Theory Framework. Procedia - Social and Behavioral Sciences, 164, 242-247. doi: http://dx.doi.org/10.1016/j.sbspro.2 014.11 .073

Willis, J. W., Mukhta Jost, Rema Nilakanta (2007). Foundation of Qualitative Research: Interpretive and Critical Approach. California: Sage Publication Inc.

Yin, R. K. (2003). Case Study Research: Design and Method (Third ed.). California: Sage Publication, Inc. 